\title{
Demand Profile Study of Battery Electric Vehicle under Different Charging Options
}

Marra, Francesco; Yang, Guang Ya; Træholt, Chresten; Larsen, Esben; Rasmussen, Claus Nygaard; You, Shi

\section{Published in:}

Proceedings of the 2012 IEEE Power \& Energy Society General Meeting

Link to article, DOI:

10.1109/PESGM.2012.6345063

Publication date:

2012

Link back to DTU Orbit

Citation (APA):

Marra, F., Yang, G. Y., Træholt, C., Larsen, E., Rasmussen, C. N., \& You, S. (2012). Demand Profile Study of Battery Electric Vehicle under Different Charging Options. In Proceedings of the 2012 IEEE Power \& Energy Society General Meeting IEEE. https://doi.org/10.1109/PESGM.2012.6345063

\section{General rights}

Copyright and moral rights for the publications made accessible in the public portal are retained by the authors and/or other copyright owners and it is a condition of accessing publications that users recognise and abide by the legal requirements associated with these rights.

- Users may download and print one copy of any publication from the public portal for the purpose of private study or research.

- You may not further distribute the material or use it for any profit-making activity or commercial gain

- You may freely distribute the URL identifying the publication in the public portal 


\title{
Demand Profile Study of Battery Electric Vehicle under Different Charging Options
}

\author{
Francesco Marra, Guang Ya Yang, Chresten Træholt, Esben Larsen, Claus Nygaard Rasmussen, and \\ Shi You
}

\begin{abstract}
An increased research on electric vehicles (EV) and plug-in hybrid electric vehicles (PHEV) deals with their flexible use in electric power grids. Several research projects on smart grids and electric mobility are now looking into realistic models representing the behavior of an EV during charging, including nonlinearities. In this work, modeling, simulation and testing of the demand profile of a battery-EV are conducted. Realistic work conditions for a lithium-ion EV battery and battery charger are considered as the base for the modeling. Simulation results show that EV charging generates different demand profiles into the grid, depending on the applied charging option. Moreover, a linear region for the control of $\mathrm{EV}$ chargers is identified in the range of $\mathbf{2 0 - 9 0 \%}$ state-of-charge (SOC). Experiments validate the proposed model.
\end{abstract}

Index Terms - charging, demand profile, electric vehicles, modeling, validation

\section{INTRODUCTION}

$\mathrm{T}$ HE electrification of transport sector, by means of batteryEV and PHEV, will most likely contribute to achieve the CO2 target in the coming years [1]. With the expected breakthrough on the market of $\mathrm{EV}$ and plug-in hybrid $\mathrm{EV}$ (PHEV) there is an increasing need to evaluate their benefits and impacts in the existing electrical systems.

Especially with battery-powered EV, there is the opportunity to achieve zero-emissions during a driving cycle since all energy needed comes from a battery [2]. At the same time, the progressive replacement of conventional vehicles with $\mathrm{EV}$ will generate an additional electrical load into the existing distribution grids.

Research on Smart Grids has proposed alternative concepts when dealing with EV, which are seen not as a mere electric load but rather as a flexible resource in the power system [3]. It has been studied in [4] how the charging process of an EV can be intelligently controlled, in order to cope with renewable power fluctuations, electricity price and local grid constraints. Coordinating the charging of a number of EV according to a pre-defined algorithm, would lead to an aggregated load profile which is significantly different from an uncoordinated scenario [5]. From the perspective of a distribution system operator (DSO), the flexibility offered by EV during charging is still seen as a demand profile that needs to be modeled. Modeling the demand of an EV acting as a flexible load in the power system represents an area which was not addressed until few years ago. In [6] the authors proposed a methodology for modeling $\mathrm{EV}$ as an additional load in the distribution grid. In the work, it is considered that the charging operation can either take place in uncoordinated manner or it can be intelligently managed during off-peak electricity hours.

Both EV and PHEV battery technologies have received great attention for modeling the charging process. The battery is the most important component of an $\mathrm{EV}$, since it characterizes the vehicle under several points of view: energy and power capacity, range, weight, cost and lifetime. Special attention is given to lithium-ion (Li-ion) battery chemistry and several methods have been used to closely model its behavior. In [7], electrochemical impedance analysis is used to estimate the parameters and derive a model for the battery. It is important to notice that this method is rather complex and deriving an accurate battery model is only possible if special equipment is available. At the same time, this method cannot describe the demand profile of EV charging, as it does not take into account different possible charging options.

In the context of Smart Grids, Virtual Power Plant (VPP) operators and DSO are asking for a simpler, yet comprehensive EV demand model, which is capable of describing in a realistic way the major variables involved during the charging process of an EV [8].

In this paper, modeling of the demand profile of a battery $\mathrm{EV}$ is performed, addressing typical aspects of different $\mathrm{EV}$ charger options. In the study, the battery modeling methodology proposed by Tremblay et al. in [9] is used. With this method the battery parameters are extracted and the battery manufacturer curves are reproduced without the need of sophisticated tools.

An integrated EV model is proposed, composed of a battery and a charger, where the vehicle State-of-Charge (SOC), the real time charging power, the voltage and current on the battery and grid sides are modeled. The paper is organized as follows: in Section II the methodology used for modeling the EV battery is described. In section III, the proposed EV model is presented.

In section IV, simulations performed in Matlab based on the defined model are presented and discussed. Validation of models is conducted in Section V, using an experimental setup.
Mr. Marra, Mr. Yang, Mr. Træholt, Mr. Larsen, Mr. Nygaard Rasmussen and Mr. You are with the Centre for Electric Technology, Department of Electrical Engineering, Technical University of Denmark, 2800 Kgs. Lyngby, Denmark (e-mail: fm@elektro.dtu.dk). 


\section{BATTERY MODEL}

The methodology presented in [9] is used in this work to model a Li-ion EV battery. The choice for such chemistry is related to the recent trends and expectations in the EV sector. According to a market report by Frost \& Sullivan [10], more than $70 \%$ of EV in 2015 will be powered by Li-ion batteries. Compared to other battery technologies, Li-ion batteries offer a series of advantages: greater energy-to-weight ratio, no memory effect and low-self discharge when not in use [11]. The model of Li-ion battery used in this study is depicted in the scheme of Fig. 1:

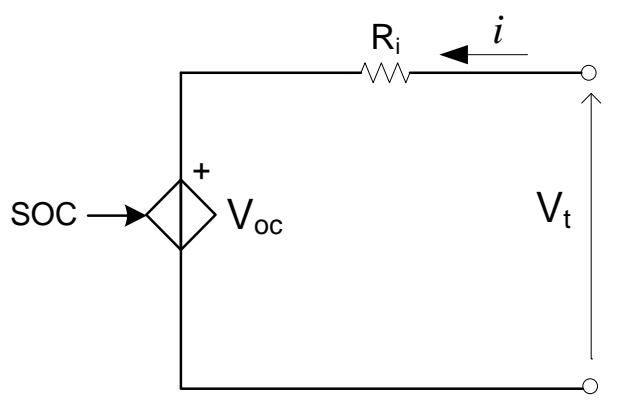

Fig. 1. EV Battery model

The model is composed by a controlled voltage source $V_{o c}$ in series with the equivalent battery cell impedance $R_{i}$. The terminal voltage of the battery is indicated with $V_{t}$. The only state variable of the model is the SOC and this is defined as follows [12]:

$$
S O C=\frac{Q}{Q_{n o m}}
$$

where

Q is the actual capacity stored in the battery, Ah

$Q_{\text {nom }}$ is the nominal capacity of the battery, Ah

If we neglect the battery efficiency during charging, the SOC variation over the time can be expressed as:

$$
\frac{d S O C}{d t}=\frac{i}{Q_{\text {nom }}}
$$

where

$i \quad$ is the charging/discharging current

The open circuit voltage of the battery $V_{o c}$ is described by the following formula according to [8]:

$$
V_{\text {oc }}(Q)=V_{0}-\frac{K \cdot Q_{\text {nom }}}{Q_{\text {nom }}-Q}+A \cdot e^{(-B \cdot Q)}
$$

where

A is the exponential zone amplitude (V)

$B \quad$ is the exponential inverse time constant (Ah) ${ }^{-1}$

$V_{0} \quad$ is the battery voltage constant (V)

$K \quad$ is the polarization voltage $(\mathrm{V})$
It is evident from (3) that the battery voltage is function of the actual stored capacity $Q$, which is another expression of the SOC level according to (2).

The parameters used to model the Li-ion EV battery are estimated from the discharging curves of a $3.2 \mathrm{~V}-40 \mathrm{Ah}$ lithium iron phosphate (LFP) battery cell, following the procedure depicted in the diagram of Fig. 2. The horizontal axis indicates the battery capacity in Ah. The vertical axis indicates the cell voltage. From the curve, it is possible to derive three characteristic points of the battery, which correspond to:

- $V_{\text {full }}$ voltage level at fully charged state

- $V_{\text {exp }}$ voltage level at end of exponential zone

- $V_{\text {nom }}$ voltage level at end of nominal zone

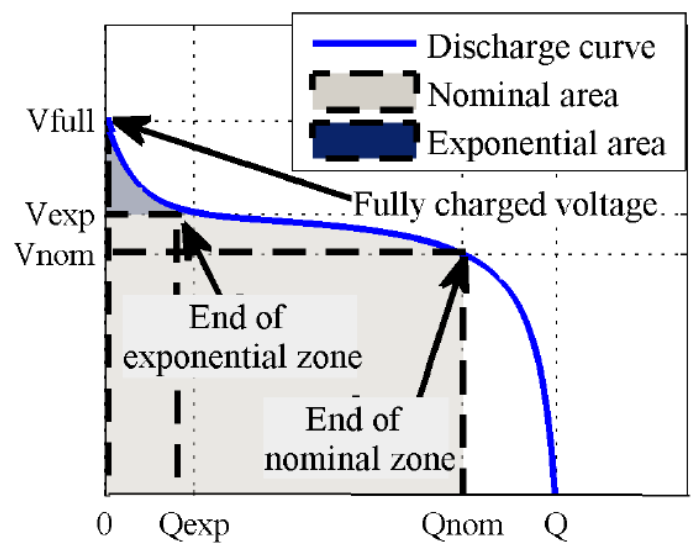

Fig. 2. Procedure for extracting the battery parameters [13]

The estimated parameters for the LFP battery are shown in Table I.

TABLE I

EV BATTERy CELl PARAMETERS

\begin{tabular}{ccccc}
\hline \multicolumn{5}{c}{ LFP 40Ah battery } \\
\hline $\mathrm{V}_{0}(\mathrm{~V})$ & $\mathrm{R}(\Omega)$ & $\mathrm{K}(\mathrm{V})$ & $\mathrm{A}(\mathrm{V})$ & $\mathrm{B}(\mathrm{Ah})^{-1}$ \\
\hline 3.5 & 0.01 & 0.025 & 0.2 & 0.375 \\
\hline
\end{tabular}

The terminal voltage of the battery cell $V_{t}$, is easily derived by adding to the expression of (3), the voltage drop due to the internal impedance $R_{i}$ :

$$
V_{t}=V_{o c}+R_{i} \cdot i
$$

The voltage drop is considered positive during charging and negative during discharging. The battery internal impedance is usually provided by the manufacturer on the battery datasheet [14]; however its value was validated to further improve the model. The impedance of the battery cell was measured with Impedance Spectroscopy method using the test equipment available at Risø DTU laboratory [15]. The measurements performed determined an internal impedance of about $10 \mathrm{~m} \Omega$. 


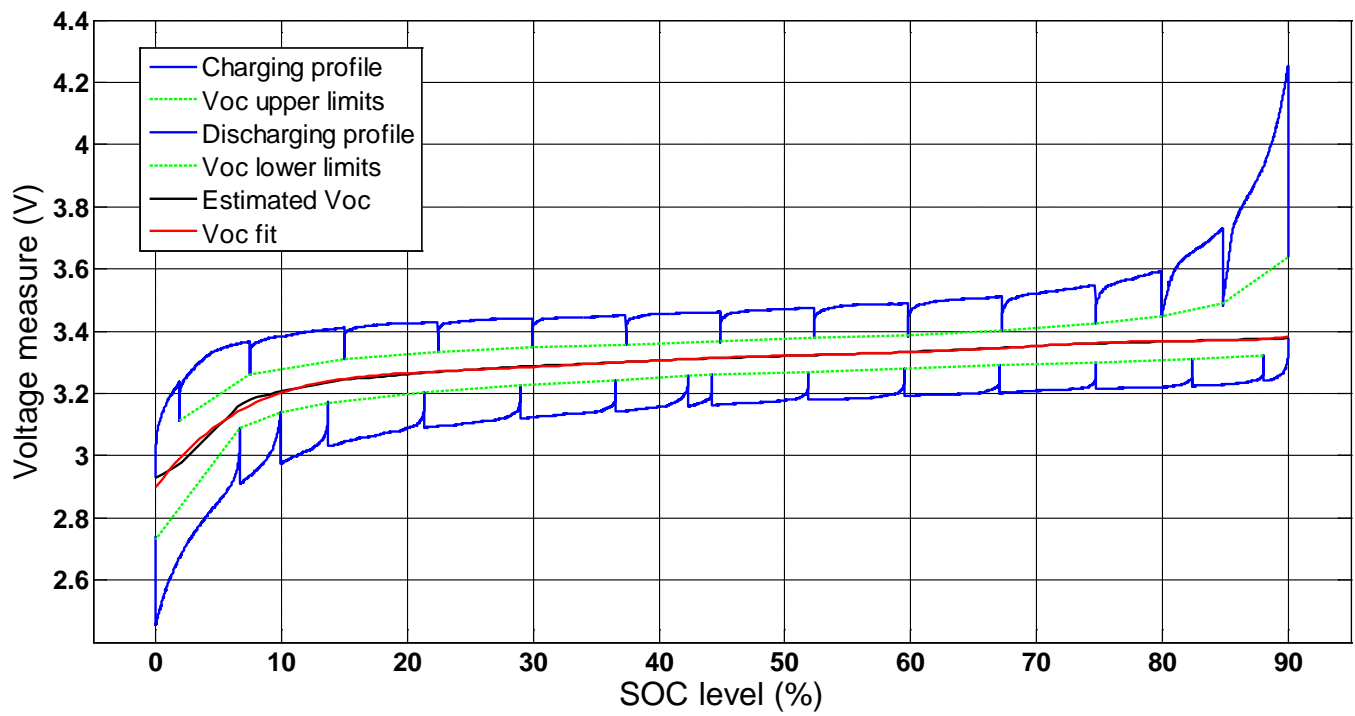

Fig. 3. Validation of voltage profile of a Li-ion EV battery with charge/discharge current of 0.5C

A separate test was conducted with the goal of characterizing the battery cell voltage as a function of the SOC. The test served also to validate the charging/discharging curves given by the manufacturer.

The following steps were followed during the test:

1. Charge with constant current, 0.5C, i.e. 20A, starting from a SOC of $0 \%(2.5 \mathrm{~V})$, till $90 \%,(4.25 \mathrm{~V})$.

2. Discharge with constant current, $0.5 \mathrm{C}$, from a SOC of $90 \%$ till $0 \%$ SOC $(2.5 \mathrm{~V})$

The Step Current method, as described in [16], was used to charge/discharge the battery and determine the open circuit voltage $V_{\text {oc }}$ profile. In Fig. 3, the measured voltage profiles are shown. During charging, it is noted a rapid increase of voltage within the SOC range of 85 to $90 \%$. Considering that for lifetime reasons a minimum SOC level of $20 \%$ is recommended [17], it can be concluded that the SOC window of $20-90 \%$ is a suitable energy window to use for EV batteries.

\section{ELECTRIC Vehicle Charging Model}

An EV model was implemented based on the diagram of Fig. 4. The model integrates the battery model described in Section II with an EV charger model. On the grid side, the EV charger is supplied with grid voltage $V_{c}$ and absorbs the current $i_{c}$ during charging. On the battery side, $V_{\text {pack }}$ and $i$ identify the terminal voltage and the current absorbed by the battery, respectively. The parameters $V c_{e q}$ and $R_{e q}$ indicate the equivalent voltage and resistance of the $\mathrm{EV}$ battery respectively. Based on the validation performed on the single cell, the electrical features of a real EV battery pack were derived and summarized in Table II. Concerning the EV demand study, a battery pack composed of 110 seriesconnected 3.2 V - 40 Ah LFP cells was considered, which leads to a total battery pack nominal voltage of $352 \mathrm{~V}$.

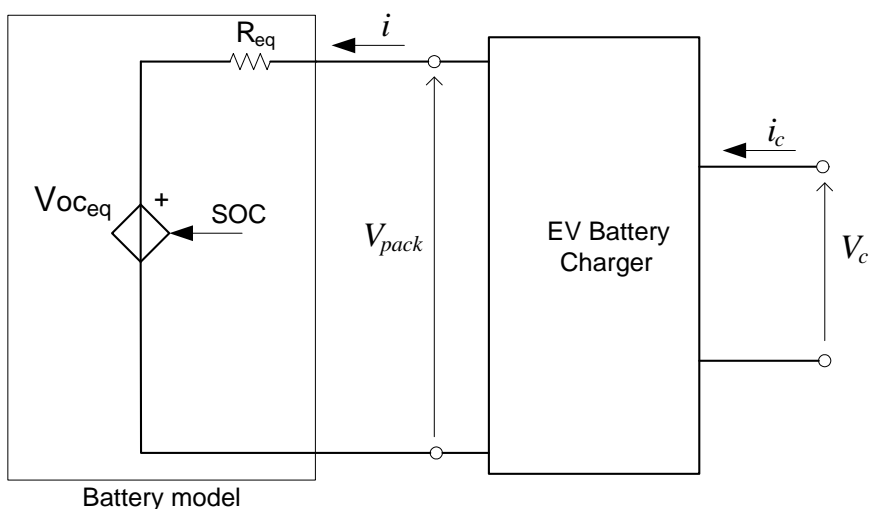

Fig. 4. EV model

TABLE II

EV BATTERY PACK PARAMETERS

\begin{tabular}{lcc}
\hline \multicolumn{1}{c}{ Parameter name } & Unit & Value \\
\hline Nominal EV battery energy, Enom & $\mathrm{kWh}$ & 14 \\
Nominal EV battery cell voltage, $\mathrm{V}_{\text {nom }}$ & $\mathrm{V}$ & 3.2 \\
Nominal EV battery voltage, $\mathrm{V}_{\mathrm{B}}$ & $\mathrm{V}$ & 352 \\
Nominal EV battery capacity, Qnom & $\mathrm{Ah}$ & 40 \\
Equivalent resistive impedance, $\mathrm{R}_{\mathrm{eq}}$ & $\Omega$ & 1.1 \\
\hline
\end{tabular}

The characteristic charging curves of a Li-ion battery are depicted in Fig. 5. On the vertical axis, the charging current level is indicated. On the two secondary axes the battery cell voltage and SOC are indicated. The green, red and blue curves represent the battery voltage, current and SOC respectively. According to most Li-ion battery manufacturers, $0.5 \mathrm{C}$ current rate is recommended for charging the battery and this corresponds also to the level stated in the battery datasheet [14]. It is evident that the standard charging algorithm of a Liion battery is composed of two distinct operational regions: constant current (CC), until the voltage upper limit is reached; constant voltage (CV), until a SOC level of $100 \%$ is reached. 


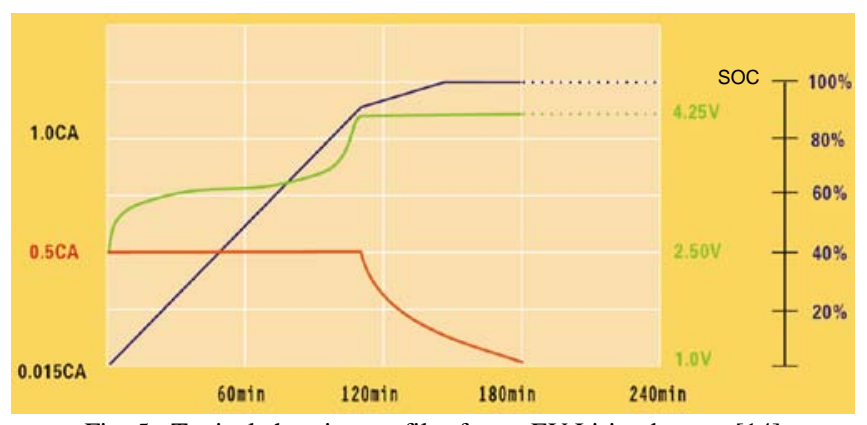

Fig. 5. Typical charging profiles for an EV Li-ion battery [14]

Although the charging curves depicted are obtainable with laboratory equipment, the same profiles are not always valid when charging a real EV battery by means of an EV charger. Different charging strategies can be employed for an EV charger and this will affect the resulting demand profile on the grid side.

In the study, an EV battery charger was modeled as a single-phase AC/DC converter with efficiency $\eta$, according to two different charging options.

\section{A. Constant Current - Constant Voltage Option}

With Constant Current - Constant Voltage charging option, the charger performs according to the following operations:

- Constant Current (CC) on the battery side, until the maximum cell voltage is reached.

- Constant Voltage (CV) on the battery side, until the battery is fully charged.

In the CC working region, the current $i$ is kept constant during charging until the cut-off voltage level is reached. In general, the power on the grid side $P_{a c}$ and battery side $P_{d c}$ are calculated as:

$$
P_{a c}=V_{c} \cdot i_{c} \quad \text { (5) } \quad P_{d c}=V_{p a c k} \cdot i
$$

Since $V_{\text {pack }}$ is a function of the SOC level of the battery from (3), it leads to $P_{a c}$ also being function of the SOC. Therefore (5) can be rewritten as:

$$
P_{a c}\left(V_{\text {pack }}\right)=V_{c} \cdot i_{c}\left(V_{\text {pack }}\right)
$$

Recalling (5) and (6), the expressions of $P_{d c}$ and $P_{a c}$ become:

$$
\begin{aligned}
& P_{a c}(S O C)=V_{c} \cdot i_{c}(S O C) \\
& P_{d c}(S O C)=V_{p a c k}(S O C) \cdot i
\end{aligned}
$$

Under the CV working region, the power $P_{a c}$ and the current $i_{c}$ are not controllable anymore. The only controlled variable is the voltage $V_{\text {pack }}$ which is constantly maintained until the SOC level of $100 \%$ is reached.

\section{B. Constant Power - Constant Voltage Option}

The other charging option available for EV chargers is Constant Power - Constant Voltage. With this option the following functions are implemented:
- Constant Power (CP), $P_{a c}=$ constant, until the maximum cell voltage is reached

- Constant Voltage (CV), $V_{\text {pack }}=$ constant, until the SOC level of $100 \%$ is reached

The power on the grid side $P_{a c}$ is kept constant during the charging process until the cell voltage threshold is reached. Considering that $V_{\text {pack }}$ increases with the SOC according to (3), the current $i$ must be regulated in order to ensure a constant charging power. Moreover, taking into account the efficiency of the charger $\eta$, the power on the battery side can be expressed as:

$$
P_{d c}=\eta \cdot P_{a c}
$$

Considering (8) and (9), $i$ can be calculated as:

$$
i(\mathrm{SOC})=\eta \cdot \frac{V_{c} \cdot i_{c}}{V_{\text {pack }}(\mathrm{SOC})}
$$

When the CV mode is entered, the same modeling issues of the previous charging option are valid.

\section{Modeling the EV battery SOC}

For both charging options, the EV battery SOC is derived from (10), considering the initial SOC condition:

$$
\begin{aligned}
& \operatorname{SOC}(k)=\sum_{k=1}^{N} \frac{d Q(k)}{Q_{n}}+S_{i} O C_{i} \\
& d Q(k)=i(k) \cdot T_{i} \\
& d S O C(k)=\frac{d Q(k)}{Q_{n}}
\end{aligned}
$$

where

$k \quad$ is the simulation's steps number

$N \quad$ is the number of steps which determines the charging duration

$T_{i} \quad$ is the reference time step

$i \quad$ is the DC current during charging

$d Q \quad$ is the capacity variation at each time step

$d S O C$ is the SOC variation at each time step

$S O C_{i}$ is the initial condition of SOC

In the CV region the capacity variation $d Q$ of the battery becomes nonlinear, as $i$ exponentially decreases over the time. For the same reason, the SOC curve enters the nonlinear region. In more general terms, working in the linear or nonlinear region of an EV battery is meaningful for a number of techno-economic reasons that will be briefly described in the following paragraphs.

\section{EV coordination and EV fleet management}

In a Smart Grid scenario, it should be possible to treat EV as a socio-economic solution, which goes beyond the scope of transportation. It is aimed to aggregate and coordinate EV, so they can participate in intelligent charging schemes, e.g. ancillary services [18]. An EV coordinator is able to coordinate EV charging provided that the battery is in the linear SOC region. All other EV charging in the nonlinear 
SOC region, i.e. CV region, cannot be included in the coordination scheme.

\section{Battery lifetime and charging efficiency}

According to common practice, several EV manufacturers limit the SOC window of a Li-ion battery in the interval [17]:

$$
S O C \in[20,90] \%
$$

The choice for such an interval relates mainly to battery lifetime aspects; charging the upper $10-20 \%$ SOC window has shown quicker battery degradation [19]. In [17] it is also recommended to avoid discharging the battery if the SOC is already below $20 \%$. From a charger perspective, the CV region is a low-efficiency working region since the charging power falls far below its nominal power [20].

\section{Charging power levels}

Due to the electrical characteristics of the low voltage grid where $\mathrm{EV}$ are going to be connected, the charging power levels commonly considered are the ones indicated in Table III.

TABLE III

CHARgING POWER LEVELS

\begin{tabular}{cccc}
\hline AC current & AC voltage & Grid connection & Power \\
\hline $16 \mathrm{~A}$ & $230 \mathrm{~V}$ & single phase & $3.7 \mathrm{~kW}$ \\
$32 \mathrm{~A}$ & $230 \mathrm{~V}$ & single phase & $7.4 \mathrm{~kW}$ \\
$16 \mathrm{~A}$ & $400 \mathrm{~V}$ & three-phase & $11 \mathrm{~kW}$ \\
$32 \mathrm{~A}$ & $400 \mathrm{~V}$ & three-phase & $22 \mathrm{~kW}$ \\
\hline
\end{tabular}

The cases are characterized by different charging current $i_{c}$ as well as by the grid connection type, single-phase or threephase.

In this paper, the single-phase $3.7 \mathrm{~kW}$ charging option is used for simulations and tests, as it is likely to become a common option for home-charging [21]. This corresponds using a $0.25 \mathrm{C}$ rate for charging the battery in the CC region.

\section{Simulations}

Simulations were conducted using Matlab to investigate the demand profiles generated by EV charging, according to the two options modelled.

The EV simulation model is made of a single-phase charger, with charging power level of $3.7 \mathrm{~kW}$ (c.a. 0.25C). Simulation results are depicted in Fig. 6-9.

In Fig. 6 (a), the power $\mathrm{P}_{\mathrm{ac}}$ and the SOC profile of the EV under CP-CV charging option are depicted. The time axis is expressed in minutes. The EV starts charging with an initial SOC of $60 \%$. The power is constant over time, until the battery cell voltage reaches $4.0 \mathrm{~V}$; this occurs after about 94 minutes. From this point, the charger enters the CV mode and the charging power decreases as well as the current. In Fig. 6 (b), the charging current $i$ on the battery side and the cell voltage $V_{t}$ are depicted. In the CP region, it is evident how the current $i$ decreases while the battery voltage increases.
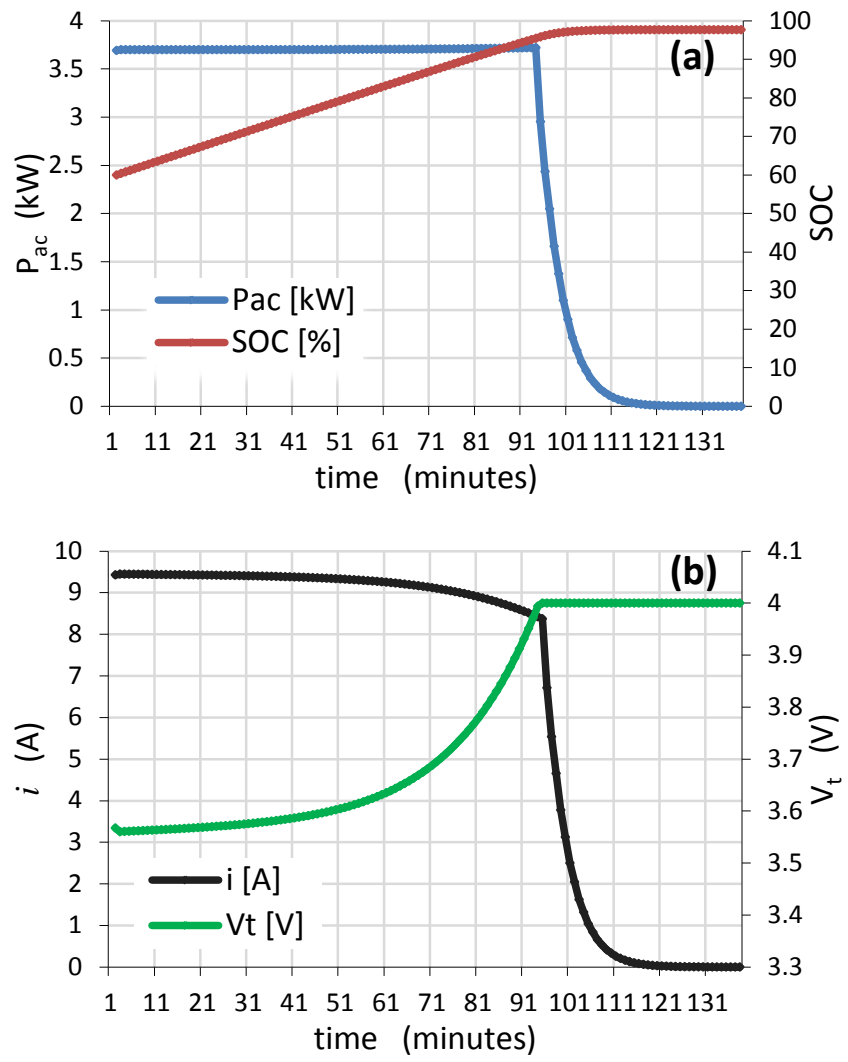

Fig. 6. Simulation of demand profile of EV charger with CP-CV option. (a) $\mathrm{P}_{\mathrm{ac}}$ and SOC. (b) Current $i$ and battery cell voltage $\mathrm{V}_{\mathrm{t}}$.
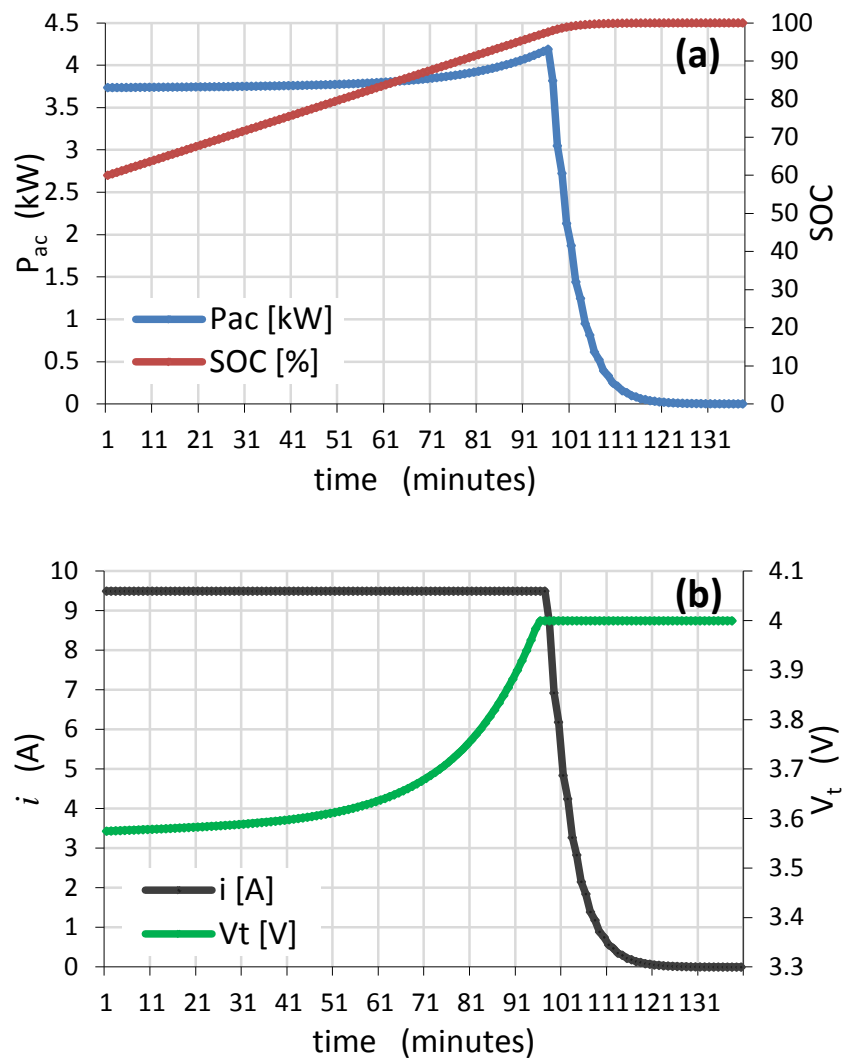

Fig. 7. Simulation of demand profile of EV charger with CC-CV option. (a) $\mathrm{P}_{\mathrm{ac}}$ and SOC profiles. (b) Current $i$ and battery cell voltage $\mathrm{V}_{\mathrm{t}}$. 


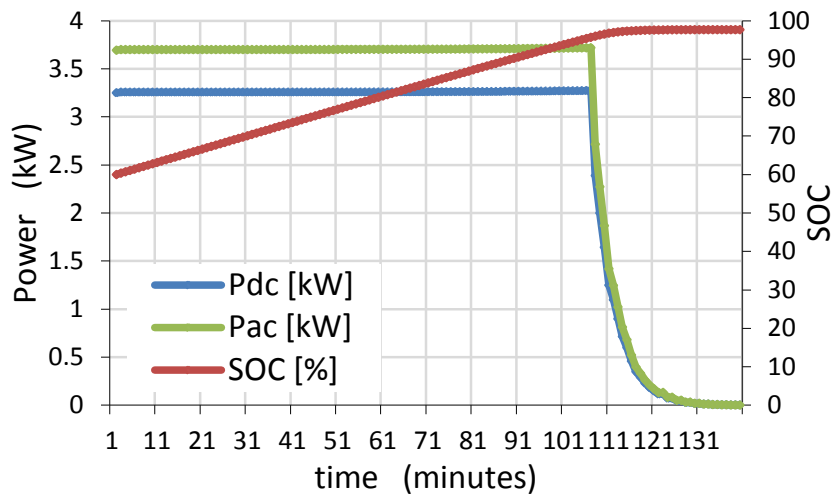

Fig. 8. Simulation of demand profile of EV charging with CP-CV option, charger efficiency $\eta=0.88, \mathrm{SOC}_{\mathrm{i}}=60 \% . \mathrm{P}_{\mathrm{dc}}, \mathrm{P}_{\mathrm{ac}}$ and SOC profiles.

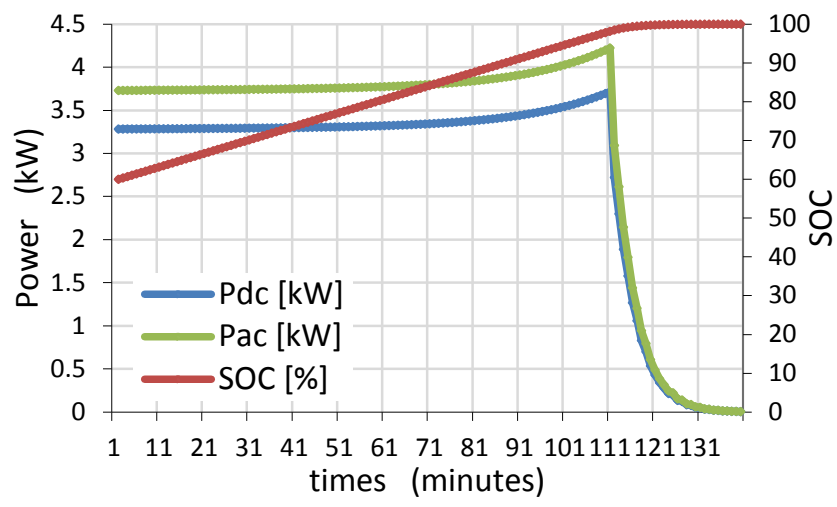

Fig. 9. Simulation of demand profile of EV charging with CC-CV option, charger efficiency $\eta=0.88, \mathrm{SOC}_{\mathrm{i}}=60 \% . \mathrm{P}_{\mathrm{dc}}, \mathrm{P}_{\mathrm{ac}}$ and SOC profiles.

In Fig. 7 (a), the charging power $P_{a c}$ and the SOC profile are depicted according to CC-CV charging option. As for the previous case, the EV starts charging with an initial SOC of $60 \%$. It is possible to note that $\mathrm{P}_{\mathrm{ac}}$ profile is not constant over the time, but it increases until the battery cell voltage reaches the maximum, i.e. after 96 minutes. From this point, the charger enters the $\mathrm{CV}$ mode and the charging power decreases accordingly. In Fig. 7 (b), the charging current $i$ and the cell voltage $V_{t}$ are depicted. It is evident that the current $i$ is constant during the CC operation, while the battery terminal voltage continues to increase. Considering same initial charging power of $3.7 \mathrm{~kW}$, charging a battery with a CC-CV charger takes few minutes less than with a $\mathrm{CP}-\mathrm{CV}$ charger. Furthermore, both charging strategies depict a linear SOC profile until about $95 \%$.

Simulations were performed again, modelling this time a charger efficiency $\eta$ of 0.88 . While the demand profiles remain similar in shape, the charging time needed is considerably longer than in the previous cases. In Fig. 8, the demand profiles of an EV charger with CP-CC option are depicted. In Fig. 9, the demand profiles of the EV charging with CC-CV option are depicted. Due to the charger efficiency, the battery charging process takes about 13 minutes longer than in the previous simulations.

\section{Model VAlidation}

The developed EV charging model was validated with an experimental setup made of real EV components. An EV battery pack with parameters as indicated in Table II was used in the tests. This is connected to an EV battery charger with parameters are shown in Table IV.

TABLE IV

EV BATTERY CHARGER PARAMETERS

\begin{tabular}{lcc}
\hline \multicolumn{1}{c}{ Parameter name } & Unit & Value \\
\hline Power range, $P$ & $\mathrm{~kW}$ & $0-5.5$ \\
Voltage range, $V_{\text {pack }}$ & $\mathrm{V}$ & $60-452$ \\
Charging current, $i$ & $\mathrm{~A}$ & $0-12$ \\
Power factor, $P F$ & - & 0.93 \\
Efficiency, $\eta$ & - & 0.88 \\
\hline
\end{tabular}

The charging process was initiated with an initial SOC of about $60 \%$, as for the simulations. The EV charger has an adjustable power level and this was set to $3.7 \mathrm{~kW}$, according to the first option in Table III. A power meter with 1-minute resolution was used to measure the active power absorbed by the charger. The charging process was remotely controlled by means of a software application which activates a circuit breaker between the charger and the grid. Test results are shown in Fig. 10. After about 95 minutes, the charging process was stopped as the cut-off voltage of $4 \mathrm{~V}$ per battery cell was reached, that corresponds to a SOC of about $90 \%$. From the measurements performed, looking at the charging power profile $P_{a c}$, it is possible to recognize a charger using CC option, with similar profile as the one obtained in simulation, Fig. 7 (a) and Fig. 9. The power absorbed by the charger increases steadily, similarly as the EV battery voltage. A power increase of $11.4 \%$ was observed at the end of the CC region, with respect to the initial power of $3.7 \mathrm{~kW}$.

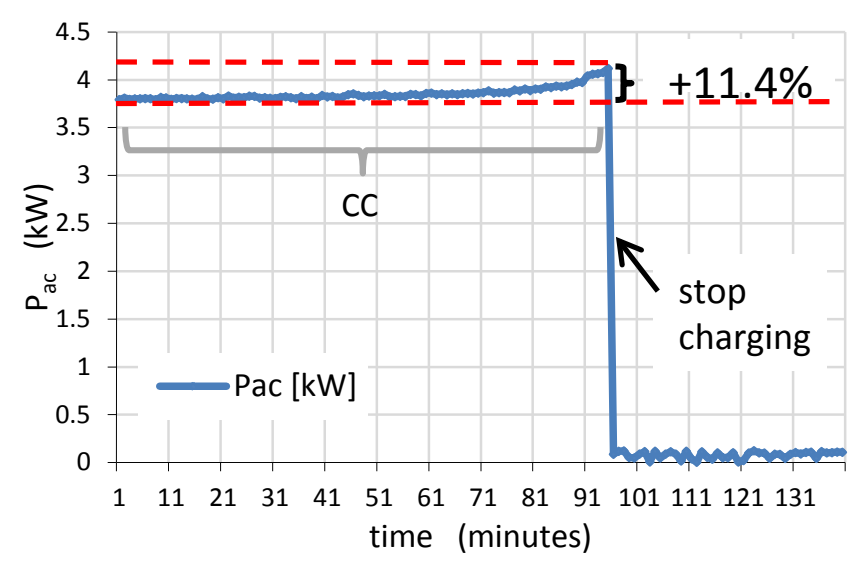

Fig. 10. Charging test of EV battery using a charger with CC-CV option

\section{CONCLUSIONS}

In this paper, the EV demand profile during a charging process was studied. The work presented a simple yet effective strategy for modelling the charging of an EV considering a validated Li-ion battery model. Simulation results have shown that the demand profile due to EV charging can have different characteristics based on the two charging options implemented by the charger. In particular, a $\mathrm{CP}-\mathrm{CV}$ charger ensures that the power level set for charging is never exceeded. On the contrary, a CC-CV charger has shown up to $11.4 \%$ additional load when the $\mathrm{CV}$ working region of 
the battery is approached. This might raise new concerns for grid constraints in residential areas.

Simulations were performed first without modelling the efficiency of the charger. Then an efficiency of 0.88 was considered in the EV charging model. In this case, the demand profiles change. Assuming the same initial SOC, the charging time resulted $14 \%$ longer than without modelling the efficiency. The demand profile of an EV charger with CC-CV charging option was validated using a full-scale EV setup, made of an EV battery pack and a battery charger.

A preferable SOC usage window was identified for an EV battery. Experimental charging/discharging tests performed on a single LFP battery cell have shown a relatively flat voltage profile up to about $80 \%$ SOC, while an exponential voltage increase from 80 to $90 \%$. Based on the findings of simulations and tests, it was determined that both charging current and power are controllable till a SOC level of about $90 \%$.

The model developed has proven reliability and can potentially be used by DSOs and EV coordinators such as Virtual Power Plant operators, in order to estimate the demand of an EV fleet or a single EV. Furthermore, the developed EV model can be used as input for dynamic modelling of EV in power system analysis.

\section{REFERENCES}

[1] European Commission, "20 20 by 2020 Europe's climate change opportunity”, COM (2008) 30 final, Brussels, 2008.

[2] K. Chen, A. Bouscayrol, A. Berthon, P. Delarue, D. Hissel, and R. Trigui, "Global modeling of different vehicles", IEEE Vehicular Technology Magazine, 2009.

[3] J. A. P. Lopes, F. J. Soares, P. M. R. Almeida, "Integration of Electric Vehicles in the Electric Power System", in Proceedings of the IEEE, vol. 99, no. 1, pp. 168-183, 2011.

[4] O. Sundström and C. Binding, "Planning Electric-Drive Vehicle Charging under Constrained Grid Conditions", in 2010 International Conference on Power System Technology (POWERCON), 2010.

[5] K. Clement-Nyns, E. Haesen and J. Driesen, "The Impact of Charging Plug-In Hybrid Electric Vehicles on a Residential Distribution Grid", IEEE Transactions on Power Systems, vol. 25, no. 1, pp. 371-380, 2010.

[6] K. Qian, C. Zhou, M. Allan, Y. Yuan, "Modeling of Load Demand Due to EV Battery Charging in Distribution Systems”, IEEE Transactions on Power System, vol. 26, pp. 802-810, 2011.

[7] K. X. Zhang, and T. Jow, "Electrochemical impedance study on the low temperature of li-ion batteries, "Electrochimica Acta", vol. 49, no. 7, pp. 1057-1061, 2004.

[8] EDISON project, “WP3 report D3.1”, www.edison-net.dk.

[9] O. Tremblay, L.A. Dessaint, A. Dekkiche, "A Generic Battery Model for the Dynamic Simulation of Hybrid Electric Vehicles", IEEE Vehicle Power and Propulsion Conference, 2007.

[10] Frost \& Sullivan, public report "M5B6-Global Electric Vehicles Lithium-ion Battery Second Life and Recycling Market Analysis”, online, 2010

[11] S. Amjad, S. Neelakrishnan, and R. Rudramoorthy, "Review of design considerations and technological challenges for successful development and deployment of plug-in hybrid electric vehicles”, Renewable and Sustainable Energy Reviews 14, pp. 1104-1110, 2010.

[12] H. He, R. Xiong, X. Zhang, F. Sun and J. Fan, "State-of-Charge Estimation of the Lithium-Ion Battery Using an Adaptive Extended Kalman Filter Based on an Improved", in IEEE Transaction on Vehicular Technology, vol. 60, n. 4, pp. 1461-1469, 2011.

[13] O. Tremblay and L. Dessaint, "Experimental Validation of a Battery Dynamic Model for EV Applications", in World Electric Vehicle Journal, Vol. 3, AVERE, 2009.

[14] Thunder Sky, LFP Battery User Manual, 2010.

[15] S. H. Jensen, A. Hauch, P. Vang Hendriksen, M. Mogensen, N. Bonanos, and T. Jacobsen, "A Method to Separate Process Conributions in impedance Spectra by Variation of Test Conditions", in Journal of the Electrochemical Society, vol. 154, no. 12, pp. 1325-1330, 2007.
[16] Min Chen and G.A. Rincon-Mora, "Accurate electrical battery model capable of predicting runtime and I-V performance", in IEEE Transactions on Energy Conversion, vol. 21, no. 2, pp. 504-511, 2006.

[17] F. Marra, C. Træholt, E. Larsen and Q. Wu, "Average Behavior of Battery-Electric Vehicles for Distributed Energy Studies”, IEEE Innovative Smart Grid Technology Conference, 2010.

[18] M. D. Galus, S. Koch, G. Andersson, "Provision of Load Frequency Control by PHEVs, Controllable Loads, and a Cogeneration Unit", in IEEE Transactions on Industrial Electronics, vol. 58, no. 10, pp. 45684582, 2011.

[19] Nissan Leaf Electric Car, Charging info, www.nissanusa.com.

[20] E. M. Marwell, E. P. Finger and E. Sands "Lead Acid Traction Batteries", in Library of Congress Catalog card 81-65733; ISBN: 0939488-00-0S, Curtis Instruments, 1981.

[21] IEC 61850 Part 7-420. 